\title{
New Policies to Facilitate Affordable Housing in Central and Eastern Europe
}

Affordable housing construction is a lagging sector in most of the CEE countries. Recent increases in housing production have mainly served the top end of the market. In some countries, policy schemes for public housing have been established. However, actual construction of housing for moderate-income households has yet to take place. Wolfgang Amann describes the approach of the Austria-based IIBW-Institute for Real Estate, Construction and Housing aimed at rectifying this unsatisfactory situation. The framework for a Public-Private Partnership (PPP) model in housing will be established, with two parallel strategies. First, a legal framework will be established to allow for a new business model of PPP housing. Second, financing tools will be implemented, similar to structured financing, implementing the different layers of sources. This approach refers to lessons learned in many Western European countries, e.g., the Netherlands and Austria, where a Third Sector in housing contributes substantially to good housing provision for large parts of the population. IIBW is currently implementing this new approach in several CEE countries, including Romania, Montenegro and Albania.

Keywords: affordable housing, housing law, housing construction, CEE countries, Romania.

\section{Introduction}

For a number of years IIBW, the Austria-based Institute for Real Estate, Construction and Housing Ltd., has been providing advice aimed at establishing affordable rental housing sectors in transition economies (e.g. Amann 2005, Amann 2006, Amann et al. 2006), based on the rationale that private housing construction is unlikely to satisfy the housing demand of low- and moderate-income households. The main aim of this paper is to outline two important requirements for providing a satisfactory supply of affordable rental housing in transition countries. It focuses on two projects already undertaken by IIBW. One of these aims to establish a legal basis and a business model for Public-Private Partnership (PPP) housing companies, while the other aims to provide long-term and stable financing for affordable rental housing in transition economies.

\section{A new Housing Law for Romania}

Commissioned by the Romanian Ministry of Development, Public Works and Housing in 2007, IIBW has developed a new Housing Law, based on European best practice while meeting EU requirements.

The rationale for this work stemmed from major inefficiencies in the Romanian rental housing sector. As a result of mass privatization in the 1990s, involving 27 per cent of the total housing stock (accounting for some 2.2 million dwellings), virtually no rental dwellings remained. There is only an informal rental sector, which is largely self-organized on an irregular basis. An estimated 1.0 million privatized condominiums are rented out privately, without any consumer protection and very often even without written contracts (Tsenkova 2005, PRC 2005, IIBW 2007).

The condominium sector has already undergone some legal reforms. However, restructuring the regulations has revealed some inconsistencies and some gaps in the regulations. Homeowners' associations are organized in a fairly operative way, but they are formed on a voluntary basis, and are consequently not widespread.
Housing management and maintenance is partially regulated within the legislation on condominiums. However, as is commonly found in all CEE countries, there is inadequate enforcement. Today, housing administration is mostly organized by individual owners, and rarely by professional service providers. Nevertheless, in Romania private initiative has achieved the licensing of administrators who are required to have taken a basic training programme. Housing maintenance continues to be a major challenge, particularly thermal refurbishment, which has only been realized in a few projects. Despite rather generous subsidies, improvements have been impeded by a decision-making process that now involves multiple owners, including many with very limited resources.

There are some subsidy programmes in place, e.g. to promote the completion of unfinished residential buildings or to shelter young families. For thermal refurbishment, subsidies of up to two thirds of the construction costs are available, but these are rarely applied. Unfortunately, subsidy programmes tend to stem from short-term political motives and for this reason lack a more strategic approach.

In order to re-establish social housing, a National Housing Agency (ANL) was established in the late 1990s. This was originally assigned to organize financing of social housing, but has since changed its focus to ownership of housing assets. Toward this aim, ANL has realized some remarkable projects, e.g. the Brâncuşi rental housing estate in Bucharest, with some 1,500 social dwellings of fairly high quality. However, the rents are set politically. They are extremely low, and the allocation of the dwellings lacks transparency. Currently, the government has decided to sell the dwellings to the sitting tenants at far below market prices, with the effect of again diminishing the newly-established social housing stock.

The proposed new Romanian Housing Law consolidates all previous regulations pertaining to housing, and supplements them with European best practice to provide a comprehensive canon of housing regulations. This includes a Housing Law as an umbrella law providing a framework to ensure legal consistency of the six laws that constitute Romanian housing legislation: a Rent Law, which resolves common deficiencies that can undermine relationships between tenants 
and landlords, a Condominium Law, a Housing Management and Maintenance Law that covers all regulations in the field of housing operation, administration, accounting, maintenance and refurbishment, and a Housing Subsidy Law that defines the legal basis for all activities of the state in (co-)financing housing construction, refurbishment, housing benefits and related activities.

IIBW has newly introduced a PPP Housing Law to establish a new type of housing provider that has shown outstanding efficiency in several European countries. It combines the functions of a housing developer, an investor and a housing administrator, and is particularly eligible for rental housing construction, the takeover of social housing stock and the refurbishment of existing residential buildings. The PPP Housing Law draws on the example of the best European models of limited-profit social housing and turns them into a model applicable to the specific environment faced by countries in transition. It combines the strengths of the markets (privately-run companies) with the backing of the state (privileged access to subsidies, public control). In this way, it is expected to promote a strong sector for the provision of affordable dwellings. The PPP housing sector is designed fully in line with European positions. The European Union has communicated quite plainly its support for the establishment of social housing sectors in the new member states. PPP housing companies fulfill public service obligations and may be compensated for these obligations without interfering with EU regulations on competition (EC 2005/179; EC 2005/842).

\section{Structured financing for PPP housing}

PPP housing legislation has been described as a strategy leading toward the establishment of a new business sector, targeting at affordable housing, particularly rental housing (UNECE 2005a, Lux 2006, Chiquier/Lea 2009). This is unambiguously a top-down approach, which requires political will to facilitate. However, in order to establish PPP housing as a new business sector, a second strategy is necessary, i.e. financing schemes that allow for affordable rents, without leaving the paths of market-based operations. Together, the aim is to develop social housing as a bankable product.

In 2005 and 2006, IIBW carried out research which paved the way for the development of a Housing Finance Agency for Countries in Transition (H!FACT, cf. Amann et al. 2006). Initiated by the Stability Pact for South Eastern Europe and in cooperation with some commercial banks and financing institutions active in the CEE countries, new ways of financing affordable housing were sought. The need for action was, and still is, evident: within the decade to come, around 5 million dwellings will be required in the CEE countries and a very large part of the existing 40 million dwellings is in urgent need of refurbishment.

The theoretical basis of our approach is built on the numerous studies that IIBW has completed concerning the Austrian system of housing finance and housing promotion (Amann \& Mundt 2005, Lugger \& Amann 2006, Lux 2006). The model for PPP housing, as executed in the PPP Housing Law for Romania and the H!FACT financing scheme, is the sector of Limited-Profit Housing Associations (LPHA) in
Austria, which dominates both the affordable rental housing market and the new residential construction market. Some 20 per cent of the total housing stock in Austria has been built by LPHAs, comprising 800,000 dwellings, around two thirds of which are rental housing units and one third of which are affordable condominiums. LPHAs are responsible for more than 60 per cent of multi-apartment new construction. Notably, social housing in Austria is rooted in an ideological background which stems both from the socialist idea of solidarity and the Catholic social doctrine. For this reason, the LPHA sector is supported by the two major political parties, the Social Democrats and the People's Party (Kemeny et al. 2001). This is certainly a significant consideration when attempting to transfer and establish a PPP housing sector in countries in transition.

The financing of affordable housing in Austria is quite complex, but nevertheless rather efficient. Even though more than 80 per cent of new construction is co-financed by the state, public expenditure on housing promotion only amounts to approx. 1.0 per cent of GDP, which is well below the Western European average. The main reason for this cost-efficiency is the focus on construction-based subsidies, specifically including the LPHA sector (Amann \& Mundt 2005). The housing products are targeted at lower and middle income groups, which may be defined as the $2^{\text {nd }}$ to the $8^{\text {th }}$ income decile. The majority of beneficiaries are able to cover their rents or annuities without a need for additional housing benefits. Hence, subject-oriented subsidies amount to only approx. 8 per cent of total public expenditure on housing policy. That is to say, the prices of LPHA rental dwellings are not cheap, but they are usually below the market prices for private rentals. With broad accessibility and a remarkable market share, LPHA rental housing has an effective influence on price levels and price development in the private market. It is mainly because of this interference that housing market prices did not shoot up in the boom period and have not slumped since 2007. For this reason, the Austrian model of rental housing may well be described as a unitary or integrated market, as classified by Jim Kemeny (1995; et al., 2001).

As private companies, LPHAs are responsible for cost-effective execution of construction works and financing. Multiple incentives contribute to sound performance, despite the limitation on profits. A typical housing project is financed 30-50 per cent with capital market mortgage loans, 30-40 per cent with low-interest public loans, 10-20 per cent with equity of the LPHA, mostly for land purchase, and up to 10 per cent with the equity of the future tenants. The subsidized public loans have a maturity of more than 25 years and interest rates of mostly only 1 per cent. The diverse financing models aim to reduce the necessary public funding, steering effective costs for the tenants below market levels and other policy targets.

The different tranches of financing have quite different characteristics. The PPP housing business model leads to a good equity position of most of LPHAs, which allows them to purchase land and afford bridging finance for the construction period from their own capital. The low-interest public loans are not just cheap money. Adherent to the strict audit and supervision of LPHA and the occasional disposition as a subordinated claim, public loans are treated as equity capital. 
For capital market financing, additional tools for increasing efficiency are in place. All major banks have special housing banks that issue tax-privileged housing construction convertible bonds. The acquired capital has to be invested in affordable housing in Austria that also qualifies for public subsidies, i.e. mainly in LPHA housing (Schmidinger 2008). This reduces the capital costs of LPHAs by about 0.8 per cent points. More than this, it turns competition of banks and borrowers upside down. As the banks are limited to investing in the affordable housing sector, they must compete for the LPHA with the best credit history. LPHAs as a whole pose very few risks due to their mostly solid equity basis, very low vacancy rates, public support and the strict auditing procedures. Capital funding with housing construction convertible bonds allows for interest rates equivalent to the Euribor flat rate for the best social housing developers (Amann \& Mundt 2005).

Combined, affordable housing finance in Austria can be considered as a low-risk model of structured financing. In contrast to more common models of structured financing in commercial real estate financing (UNECE 2005c), it not only lowers the capital costs, but also contributes to the stabilization of financing markets (Springler 2008).

Based on this model, the following principles for financing affordable housing in Transition Economies have been developed (H!FACT financing):

\section{Legal framework}

As financing is bound to public funding, a legal framework is essential, and this is achieved via PPP housing legislation. Both PPP housing and H!FACT financing are top-down approaches, which require a clear commitment of the state authorities in a target country.

\section{Affordability}

This is basically defined with cost coverage. It means condominiums at own costs and rents of about $2 \mathrm{EUR} / \mathrm{m}^{2}$ usable floor space. This is only possible by drawing on public support on several levels. Rents and prices shall never be determined by political decision, but in principal by sound financing schemes. Mortgages have to be repaid from rent incomes, which rise according to CPI or slightly above. The break-even should not exceed 10-15 years.

\section{Target groups}

Beneficiaries of affordable rental housing shall be households from the $2^{\text {nd }}$ to the $6^{\text {th }}$ income decile, i.e. lower and middle income groups. Affordable condominiums may address even higher income groups. Lowest income groups and vulnerable households may be served as well, but require additional housing allowances. There shall be no housing estates with predominantly lowest income households. The inclusion of lowest income groups is a social policy task and has to follow criteria for integrative development of communities.

\section{Consumer choice}

The share of rental dwellings and condominiums shall be determined by transparent parameters, such as availability of retail financing for buyers or equity of the developer, but first and foremost by demand and consumer choice. Rental housing shall be established in such a way that it is economically rational for tenants to go into rental markets instead of condominiums.

\section{Management and maintenance:}

Today, a big part of the housing stock lacks sound management and maintenance. The H!FACT financing scheme includes monthly fees for operating costs of the building, including housing administration, costs for common parts, sewage disposal, savings for a reserve fund and others. These costs are estimated to be $0.50 \mathrm{EUR} / \mathrm{m}^{2}$ usable floor space.

\section{Subsidies}

These must be available. They may be low interest loans of 30-40 per cent of construction costs or grants of about half the amount.

\section{Cooperation with municipalities}

H!FACT financing requires the cooperation of municipalities. Land and infrastructure should be provided free of charge, by concession or at a low price. In return, municipalities should play a major role in allocating the dwellings. H!FACT financing will apply to very different local markets. Compared to western European states, countries in transition show much higher economic disparities between underdeveloped areas and areas of strong economic development. There is an urgent need for affordable housing in both poor and rich areas, but of course the ability to pay differs widely.

\section{Equity}

The housing developer (PPP housing company) should have sources of equity to invest in affordable housing. This will be rather limited at the commencement of operations, but may grow to a substantial quantity over time.

\section{Cross-subsidies}

Sources of cross-subsidies should be tapped, i.e. from richer to poorer regions, from for-profit condominiums or from commercial space to affordable rental dwellings.

\section{International Financing Institutions (IFIs)}

H!FACT financing includes international financing sources. The most helpful sources are mortgage loans from the housing fund DIGH - Dutch International Guarantees for Housing. These loans are guaranteed by Dutch housing associations to cover the risk of first loss. Hence, they are regarded as being equal to equity capital. In the medium term, other international financing institutions shall be attracted.

\section{Capital market financing}

This is addressed for bridging-financing during the construction period and, in the medium term, for strategic long-term investments in rental housing. Taking the risk position of the other tranches, capital market financing shall be addressed only for senior loans with appropriate conditions. Affordable rental housing may develop as an important property sector attracting investment from the capital market, as shown in Austria and Switzerland (UNECE 2005b). Decreasing the risk involved in housing finance will be a major requirement for securing future financial involvement by commercial banks. 


\section{Allocation of dwellings}

This must follow transparent procedures. Similar to the housing developer, who is bound to limitation of profits, the tenant shall be limited in her/his right to 'cash up' or extract public subsidies. Resale of affordable condominiums shall be allowed only at regulated prices for a defined period, e.g. ten years. Subleasing of affordable rental dwellings shall be prohibited.

A sizeable rental sector has important functions for a national economy, far beyond social policy goals. Rental housing not only offers low entry prices, it also promotes mobility of the workforce. A rental market for housing is crucial for young households and domestic migrants who have not accumulated sufficient capital to access the financial and mortgage markets for home purchase. In the long run, establishing a rental market offers substantial institutional investment opportunities. Altogether, affordable housing should be developed which integrates social and private rents, following the integrated market concept of Jim Kemeny (1995; et al., 2001) (see above). The supply of affordable condominiums and rental dwellings should be developed to sufficient and considerable quantities in order to influence and stabilize the private markets.

H!FACT financing is of course in line with EU legislation, particularly regarding state aid. Analyzing current jurisdiction, a set of rules can be identified: clear definition of services of general economic interest in the field of social housing (target groups), limitation of subsidies to additional costs of these services, and transparent and separate accounting principles (EC 2005/179, ECR I-7747/2003 The "Altmark Trans GmbH" Case). The new financing model may very well be combined with PPP housing legislation. This has been proved compliant with EU legislation.

The financing model described above has been applied to Montenegro and is in preparation for application to Albania.

\section{References}

[1] Amann, W.: How to boost rental housing construction in CEE-/SEE-Countries, The Housing Finance International Journal, IUHE, 12/2005, 2005.

[2] Amann, W., Beijer, E., Komendantova, N., Neuwirth, G., Roy, F., Schimpel, M., and Schwimmer, W.: H!FACT A Housing Finance Agency for CEE/SEE. Feasibility Study, Vienna: IIBW 2006.

[3] Amann, W., Mundt, A.: The Austrian System of Social Housing Finance, 2005, www.iibw.at.

[4] CGFS - Committee on the Global Financial System: The Role of Ratings in Structured Finance Issues and Implications, Bank for International Settlements, 2005.

[5] Chiquier, L., Lea, M.: Housing Finance Policy in Emerging Markets, Washington: The World Bank, 2009.

[6] Dübel, H.-J., Brzeski, W. J., Hamilton, E.: Rental Choice and Housing Policy Realignment in Transition, Post-Privatization Challenges in the Europe and Central Asia Region, Washington: The World Bank, 2006.

[7] EC (2005/179): Community Framework for State Aid in the Form of Public Service Compensation.
[8] EC (2005/842): Commission Decision of 28 November 2005 on the Application of Article 86(2) of the EC Treaty to State Aid in the Form of Public Service Compensation Granted to Certain Undertakings Entrusted with the Operation of Services of General Economic Interest.

[9] EC (2006/1080): Regulation of the European Parliament and of the Council of 5 July 2006 on the European Regional Development Fund and repealing Regulation (EC) No 1783/1999.

[10] EC (2006/177): Communication from the Commission. Implementing the Community Lisbon programme Social services of general interest in the European Union.

[11] European Court (ECR I-7747/2003): The "Altmark Trans GmbH" Case.

[12] IIBW (Ed.): Implementation of European Standards in Romanian Housing Legislation. Final Report. Research study commissioned by the Romanian Ministry of Development, Public Works and Housing. With the collaboration of Wolfgang Amann, Ioan A. Bejan, Helmut Böhm, Nadeyda Komendantova, Mihai Mereuta, Alexis Mundt, Theo Österreicher, Ciprian Paun, Gerhard Schuster, Andreas Sommer, Arin O. Stanescu, Walter Tancsits. Vienna: IIBW, 2007.

[13] Kemeny, J.: From Public Housing to the Social Market, Rental Policy Strategies in Comparative Perspective, London: Routledge, 1995.

[14] Kemeny, J., Andersen, H. T., Matznetter, W., Thalman, P.: Non-Retrenchment Reasons for State Withdrawal, Developing the Social Rental Market in Four Countries. Institute for Housing and Urban Research Working Paper 40, Uppsala University, 2001.

[15] Kemeny, J., Kersloot, J., Thalmann, P.: Non-profit Housing Influencing, Leading and Dominating the Unitary Rental Market. Three Case Studies, in: Housing Studies, Vol. 20 (2005), No. 6, p. 855-872.

[16] Lugger, K., Amann, W. (Ed.): Der soziale Wohnbau in Europa. Österreich als Vorbild, Vienna: IIBW, (2006). Amann, W., Ball, M., Birgersson, B., Ghekiere, L., Lux, M., Mundt, A., Turner, B.

[17] Lux, M.: Gemeinnütziges Wohnen eine Herausforderung für Mittel-Ost- und Südost-Europa, in: Lugger/Amann (Ed.) 2006, p. 77-91.

[18] PRC Bouwcentrum International: Sustainable Refurbishment of High-Rise Residential Buildings and Restructuring of Surrounding Areas in Europe, Report for European Housing Ministers . In: Conference proceedings 14-15 March 2005, The Netherlands: PRC, 2005.

[19] Tsenkova, S.: Housing Policy Reforms in Post-Socialist Europe. Lost in Transition, Heidelberg: Physica, 2009.

Wolfgang Amann

e-mail: amann@iibw.at

IIBW

PB 2

1020 Vienna, Austria 